\title{
The Effect of STAD Technique on the Idiom Learning of Low-Intermediate Institute Language Learners
}

\author{
Shokoufeh Safari, Shaban Berimani \\ Department of English Language, Sari Branch, Islamic Azad University, Sari, Iran \\ Email address: \\ Shokoufe.safari@yahoo.com (S. Safari),sh_barimani45@yahoo.com (S. Berimani)
}

To cite this article:

Shokoufeh Safari, Shaban Berimani. The Effect of STAD Technique on the Idiom Learning of Low-Intermediate Institute Language Learners. Science Journal of Education. Vol. 3, No. 2, 2015, pp. 30-36. doi: 10.11648/j.sjedu.20150302.13

\begin{abstract}
Learning a language is learning how to communicate in culturally, socially and academically in appropriate ways consistent with the norms and customs of the target language users. Cooperative learning as a technique used by teachers can assist students in improving essential social skills. This study aimed to investigate the effect of STAD technique on learning idioms of low-intermediate EFL learners. In addition, it aimed to compare the idiom learning of male and female language learners based on STAD. Sixty low-intermediate language learners were selected from No'andishan language institutes in Sari. Oxford Placement Test and the idiom learning package test were used in this study. Results showed that there was a significant difference between the mean scores of the two groups on the posttest of the idiom. The STAD group performed better on the post-test of idiom. No significant difference between the mean scores of the males and females on the posttest of the idiom was found.
\end{abstract}

Keywords: Cooperative learning, idiom learning, social skill, STAD

\section{Introduction}

One of the most important objectives of teachers is to efficaciously use instructional methods to improve or develop student's cognitive and affective outcomes. In recent years, studies involving cooperative learning as one kind of student-centered approach have emerged as an internationally important area of social science research among researchers (Salvin, 2011). It is clear that engagement in learning another language lies in students communicating in that language.

Moreover, as suggested by $\mathrm{Yu}$ (1995), a teacher's familiarity with cooperative learning could affect the results of such teaching method. Lia (2002) also suggests that the teacher needs prior training to obtain professional competence of cooperative learning. Cooperative learning as a technique used by teachers can assist students in improving essential social skills. It is one of the basic tools in communicative language teachers' box because groups provide so many chances for learners to communicate and a means of integrating, listening, speaking, reading, and writing (Harmer 2001).

Healthy interaction skills, success of the individual student and group members, and formation of personal and professional relationships are the result of cooperative learning (Jonson \&Jonson, 1999). Zakaria, et al (2010) concluded that positive changes take place when a teacher changes his teaching method to a more students-centered approach.Lots of studies have been carried out in different education contexts using different kinds of cooperative learning techniques. Examples include Learning Together (LT), Jigsaw Grouping, Teams-Games-Tournaments (TGT), Group Investigation (GI), Student Team Achievement Division (STAD), and Team Accelerated Instruction (TAI). A series of research studies found an appreciate relationship between the higher cognitive and affective outcomes and cooperative learning approaches (Johnson \& Johnson, 2005; Tran \& Lewis, 2012).

In Student Teams-Achievement Divisions (STAD) (Slavin, 1994), students are assigned to four-member learning teams that are mixed in performance level, gender, and ethnicity. The teacher presents a lesson, and then students work within their teams to make sure that all team members have mastered the lesson. Finally, all students take individual quizzes on the material at which time they may not help one another.

Cooperative learning is beneficial and the resulting learned skills would be reflected in future work on the job through project teams and group work (Mcardle, 2005). Learning to speak a foreign language requires more than knowing its 
grammatical and semantic rules. Learners must also acquire knowledge of how native speakers use the language in the context of structured interpersonal exchange, in which many factors interact.In contexts such as Iran with rather nonflexible conventions there should be a call on the part of curriculum makers to use these innovatory practices without to improve their educational programs.It is likely that positive interdependence among all group-mates encourages learners to help each other and exert more effort to achieve group success while in the non-cooperative classroom negative interdependence is discouraging since the success of some students, especially high achievers, may result in decreasing the opportunities for their low achieving counterparts.

STAD strategy aims at improving the language skills by emphasizing the cooperative learning between the teacher and language learners and language learners themselves. The purpose of the study is to investigate the effect of student's team achievement division (STAD) strategy on learning idioms of low-intermediate EFL learners. In addition, it aims to compare the idiom learning of male and female language learners based on STAD. One of the main purposes of learning idioms in a foreign language is to enable language learners to speak like a native speaker as much as possible. To be fluent and successful language learners, learners need to master idioms to perform well in linguistic situations.

\section{Review of the Related Literature}

\subsection{Definitions of Cooperative Learning}

Cooperative learning methods came to be noticed and widely used by teachers throughout the world in 1970s as a result of the advent of constructivist approaches and social interactionist theories to language teaching mostly influenced by the ideas of Vygotsky and Piaget. This method proved to be helpful and increased in popularity within the realm of language teaching and learning. Therefore, at the very beginning it seems necessary to review some of the definitions of cooperative learning proposed by different scholars. The term cooperation has been defined by many researchers in different yet similar ways. Pantiz (1997) considers cooperation as a "structure of interaction designed to facilitate the accomplishment of a specific end product or goal through people working together in groups" (p. 1).

Cooperative learning is defined by Bejarano $(1987$, p.1) as "a teaching strategy involving children's participation in small group learning activities that promote positive interaction". Rivers (1981) maintained that in individualistic structure, there is no interrelation between the achievements of students involved. Here, the one person's success is independent of another's. The students' achievements are usually evaluated on a criterion-referenced basis. In competitive situation, students compete to achieve their individual goals. The students are usually evaluated on a norm-referenced basis. This tends to create a negative interdependence in the class because students perceive that they can obtain good grades when other students do worse.

\subsection{Models of Cooperative Learning}

Bejarano (1987) stated that there are many different forms of small group cooperative techniques, but all of them involve having students work in small groups or teams to help one another according to the principles of positive interdependence, individual accountability, face-to-face promotive interaction, and group processing. In order to be familiar with these different forms, following sections are devoted to present a short description of the main models of cooperative learning. These models include: Cooperative Learning Structures, Discussion Group, Group Investigation (GI), Jigsaw, Learning Together, Peer Tutoring, Student Teams-Achievement Divisions (STAD).

\subsection{Student Teams-Achievement Divisions (STAD)}

Perhaps the most important model of CL which is highly used by teachers is STAD. It was developed by Robert Slavin and his colleagues at the John Hopkins University. STAD has been used in such diverse subject areas as math, language arts, social studies, and science. In Student Teams-Achievement Divisions (STAD) (Slavin, 1994), students are assigned to four-member learning teams that are mixed in performance level, gender, and ethnicity. STAD has five major components. These are class presentation, team study, quizzes, individual improving scores, and team recognition (Slavin, 1995).The teacher presents a lesson, and then students work within their teams to make sure that all team members have mastered the lesson. Finally, all students take individual quizzes on the material, at which time they may not help one another. Students' quiz scores are compared to their own past averages, and points are awarded on the basis of the degree to which students meet or exceed their own earlier performance. These points are then summed to form team scores, and teams that meet certain criteria may earn certificates or other rewards. In a related method called Teams-Games-Tournaments (TGT), students play games with members of other teams to add points to their team scores. STAD and TGT have been used in a wide variety of subjects, from mathematics to language arts to social studies, and have been used from second grade through college. The STAD method is most appropriate for teaching well-defined objectives with single right answers, such as mathematical computations and applications, language usage and mechanics, geography and map skills, and science facts and concepts. However, it can easily be adapted for use with less well-defined objectives by incorporating more open-ended assessments, such as essays or performances (Shaaban \& Ghaith, 2005).

\subsection{Idioms and Idiom Learning}

An idiom is a group of words that has a special meaning that is different from the ordinary meaning of each separate word. According to Hamidi and Montazeri (2014), idioms are inseparable elements of movies, talk shows, reality shows, and casual conversations. Idioms are indispensable components of language learning, especially in oral communication. Idioms share cultural and historical information and broadens 
people's understanding and manipulation of a language (Ambrose, 2000). Among the various definitions of idioms are: (1) the language peculiar to a people, country, class, community or, more rarely, an individual; (2) a construction or expression having a meaning different from the literal one or not according to the usual patterns of the language It is the second definition which is the focus of this thesis (Ambrose, 2000)

According to Ambrose (2000), idioms include all the expressions we use that are unique to English, including clichés and slang. Prepositional usage is also a common part of idiomatic expressions, but our focus here is on idioms as used in figurative language. The following sentence contains two idioms: He got a new car, he was in cloud nine. He decided to throw a party.

According to Gillett (2004), idioms are a cluster of words or phrases that have a meaning of their own peculiar to that language. For example, we have said above that learning English with us will be a piece of cake - now, you cannot take the meaning of "a piece of cake" in the literal sense; you have to understand it in the idiomatic sense, in which it means "easy" (Gillett, 2004).

\section{Methodology}

\subsection{Participants}

The sample of this study consisted of 60 low-intermediate language learners from five classes in No'andishan language institutes in Sari. They were selected based on a convenient random sampling. Their ages ranged from 18 to 25 years old. The participants have been learning English for about four years, and have reached the low-intermediate level. One class (21 students) was the experimental group and the other class (21 students) the control group. In the experimental group, STAD technique was used. Participants were selected among male and female language learners. There were 10 males and 11 females in both the experimental and the control group. All were in the low intermediate group.

In this class, the participants were divided into six heterogeneous groups. Each group had five students. Heterogeneous groups were selected according to the results of a Learning Style Preference Questionnaire and the grades of an English achievement test. Intervention in the experimental group was taken place one and a half months after the beginning of the semester.

A general proficiency test, in a convenient sampling format was administered to the students on two different days, since it was not possible for the whole students to come on the same day. To obtain the sample required for the experiment, 60 students from three different classes were chosen and the Oxford test was administered. After the test, forty-two students were considered homogenized based on one SD below and one SD above the mean. They were then randomly put in two groups, one experimental and one control. The researcher was the teacher of the classes, so there was no limitation on conducting the research in her own classes held two times a week for six weeks.

\subsection{Instruments}

Two instruments were used in this study: Oxford Placement Test and the idiom learning package test. The Oxford Placement Test was used as a language proficiency test. Idioms were taken from a book named "speak English like an American" by Amy Gillet. The idiom learning package test was used for two purposes: First, to find out whether language learners are at the same level of idioms' knowledge or not. Second, this package was used as both pre and post-test for the idiom section.

To be sure about the validity of pre- and post-tests, they were checked and confirmed. The pre-test and post test were previously validated through a pilot study. The reliability of the tests was checked by Cronbach's alpha coefficient. The internal consistency reliability of the test was estimated at 0.82 for pre-test and 0.84 for the post-test which shows they are highly reliable.

\subsection{Procedure}

First, the researcher selected 60 participants of low-intermediate classes from No'andishan language institutes. Then she considered forty-two of them as homogenized participants after administering the OPT test. Then the idiom learning package test was given to the participants to find out whether they were at the same level of idioms' knowledge or not. One of the classes was randomly considered as the experimental group (21 language learners) which was exposed to the treatment for six weeks, two sessions each week. The other class taken as the control group (21 language learners) was deprived of the treatment. The teacher made test was piloted in "Sara language institute" using KR21 method. Another technique which was performed for three lessons was "Jigsaw". During one term, the treatment was implemented. The post-test was administered thereafter at the end of the term.

The participants were regularly reminded of how to work together in their groups and the importance of helping each other. Whenever possible, they were encouraged to engage in group processing at the end of the class so as to reflect on how well they worked together and how they could improve next time. The control group also received instructions in learning the idioms through traditional methods such as audio-lingual method for six weeks, two sessions each week. At the end of the twelve sessions, the participants were given the post-test to see if the treatment was significantly affective in the language learners' idiom learning.

\section{Results}

\subsection{Homogeneity Test Analysis}

In order to have homogenized participants in terms of their general English language proficiency, the Oxford Placement Test (OPT) was administered. The descriptive statistics for the OPT test is displayed in the following table. 
Table 4.1. The Descriptive Statistics of the OPT score

\begin{tabular}{|c|c|c|}
\hline \multicolumn{3}{|c|}{ Statistics } \\
\hline \multicolumn{3}{|c|}{ OPT Proficiency } \\
\hline \multirow{2}{*}{$\mathrm{N}$} & Valid & 60 \\
\hline & Missing & 0 \\
\hline \multicolumn{2}{|c|}{ Mean } & 54.9667 \\
\hline \multicolumn{2}{|c|}{ Median } & 58.0000 \\
\hline \multicolumn{2}{|c|}{ Mode } & 63.00 \\
\hline \multicolumn{2}{|c|}{ Std. Deviation } & 9.89430 \\
\hline \multicolumn{2}{|c|}{ Variance } & 97.897 \\
\hline \multicolumn{2}{|c|}{ Minimum } & 34.00 \\
\hline \multicolumn{2}{|c|}{ Maximum } & 67.00 \\
\hline \multicolumn{2}{|c|}{ Sum } & 3298.00 \\
\hline
\end{tabular}

Out of the sixty participants, forty-two were considered as homogenous members. To obtain the sample required for the experiment, 60 students from three different classes were chosen and the Oxford test was administered. After the test, forty-two students were considered homogenized based on one SD below and one SD above the mean. They were then put randomly in two groups of control and experimental, twenty-one in each group.

In order to have homogenized participants in terms of their idiom knowledge, forty-two participants who were considered as homogeneous members by the proficiency test were randomly put into one experimental and one control group. The mean scores of the two groups on the idiom homogeneity test were calculated and compared. It is worth mentioning that this thirty-item test proved to be reliable in this context. The reliability index calculated through KR-21 formula was 0.826 .

Descriptive statistics for the two groups concerning their idiom proficiency test are displayed in following tables. The descriptive statistics are shown in table 4.2 below.

Table 4.2. Group statistics for the idiom proficiency test

\begin{tabular}{|c|c|c|c|c|c|}
\hline \multicolumn{6}{|l|}{ Group Statistics } \\
\hline & Group & $\mathbf{N}$ & Mean & Std. Deviation & Std. Error Mean \\
\hline \multirow{2}{*}{ ContExp Idiom } & control & 21 & 42.8571 & 16.80264 & 3.66664 \\
\hline & experimental & 21 & 41.7619 & 14.87247 & 3.24544 \\
\hline
\end{tabular}

Before choosing the appropriate statistical method, the normality of distribution had to be checked. Table 4.3 below

shows the result of the Shapiri-Wilknormality test.

Table 4.3. Tests of Normality

\begin{tabular}{lllllll}
\hline & \multicolumn{5}{l}{ Kolmogorov-Smirnov ${ }^{\mathbf{a}}$} & \multicolumn{2}{c}{ Shapiro-Wilk } \\
\cline { 2 - 7 } & Statistic & df & Sig. & Statistic & df & Sig. \\
\hline Idiom Cont & .144 & 21 & $.200^{*}$ & .908 & 21 & .051 \\
Idiom Exp & .162 & 21 & .152 & .933 & 21 & .162 \\
\hline
\end{tabular}

a. Lilliefors Significance Correction

*. This is a lower bound of the true significance.

As it can be seen in table 4.3 above, the result of the Shapiri-Wilk test shows that both sets of scores enjoyed normal distribution ( $\mathrm{p}>0.05$ for both idiom control and idiom experimental groups).

Table 4.4. The Levene's and independent t-test of the idiom homogeneity test

\begin{tabular}{|c|c|c|c|c|c|c|c|c|}
\hline \multicolumn{9}{|c|}{ Independent Samples Test } \\
\hline & & \multicolumn{2}{|c|}{$\begin{array}{l}\text { Levene's Test for } \\
\text { Equality of Variances }\end{array}$} & \multicolumn{5}{|c|}{ t-test for Equality of Means } \\
\hline & & $\mathbf{F}$ & Sig. & $\mathbf{T}$ & df & Sig. (2-tailed) & Mean Difference & Std. Error Difference \\
\hline ContExp & Equal variances assumed & .466 & .499 & .019 & 40 & .985 & .09524 & 4.89664 \\
\hline Idiom & Equal variances not assumed & & & .019 & 39.419 & .985 & .09524 & 4.89664 \\
\hline
\end{tabular}

The mean scores for the control and the experimental groups were 42.85 and 41.76 , respectively. It should be noted that the two groups were also homogenous in terms of their variances. As displayed in table 4.4., the Levene F of .466 had a probability of 0.499 . Since the probability associated with the Levene F was higher than the significance level of .05, it could be concluded that the two groups enjoyed homogenous variances. Moreover, since the probability of $t(.019)$ had the sig (.985), that is higher than the significance level of .05, it could be reasoned that the two groups were homogeneous regarding their knowledge of idioms. According to the results, it could be concluded that there was not any significant difference between the mean scores of the two groups on the idiom test of proficiency $(t(40)=.019, p>0.05)$.

\subsection{Reliability Analysis}

The reliability of the idiom test (used as pretest and post-test) as seen in table 4.5 below was computed through KR-21 formula which shows the reliability of .826 which means that the test is reliable in this context. 
Table 4.5. Reliability statistics of teacher-made idiom test

\begin{tabular}{lll}
\hline Test & KR-21 formula & N of Items \\
\hline Pretest Idiom & 0.826 & 32 \\
Posttest Idiom & 0.845 & 32 \\
\hline
\end{tabular}

\subsection{Pretest-Posttest Comparison of the Idiom Test Within Both Groups}

Before comparing the mean scores of the two groups on the posttest, the researcher made a comparison within both groups considering the pretest and posttest for each. Table 4.6 below shows descriptive statistics

Table 4.6. Descriptive statistics of the two groups considering pretest and posttest

\begin{tabular}{llllll}
\hline & & Mean & N & Std. Deviation & Std. Error Mean \\
\hline \multirow{2}{*}{ Pair 1 } & Cont Pretest & 32.3810 & 21 & 7.78766 & 1.69941 \\
& Cont Posttest & 54.7619 & 21 & 9.79237 & 2.13687 \\
\multirow{2}{*}{ Pair 2 } & Exp Pretest & 32.4762 & 21 & 8.02259 & 1.75067 \\
& Exp Posttest & 60.8571 & 21 & 12.21182 & 2.66484 \\
\hline
\end{tabular}

This pre-test, posttest comparison helps the researcher find out whether the groups had any change or progress within

themselves after the specified period.

\subsection{Posttest Comparisons}

Table 4.7. Group statistics of the posttest of idioms between the two groups

\begin{tabular}{|c|c|c|c|c|c|}
\hline \multicolumn{6}{|l|}{ Group Statistics } \\
\hline & Group & $\mathbf{N}$ & Mean & Std. Deviation & Std. Error Mean \\
\hline & control & 21 & 54.7619 & 9.79237 & 2.13687 \\
\hline ConExp Posttest & experimental & 21 & 63.0476 & 14.41345 & 3.14527 \\
\hline
\end{tabular}

The mean of the experimental and control groups are 63.04 and 54.76 respectively.

Table 4.8. Independent t-test for the posttest of idiom between the two groups

\begin{tabular}{|c|c|c|c|c|c|c|c|c|}
\hline \multicolumn{9}{|c|}{ Independent Samples Test } \\
\hline & & \multicolumn{2}{|c|}{ Levene's Test for Equality of Variances } & \multicolumn{3}{|c|}{ t-test for Equality of Means } & \multirow[b]{2}{*}{$\begin{array}{l}\text { Mean } \\
\text { Difference }\end{array}$} & \multirow[b]{2}{*}{$\begin{array}{l}\text { Std. Error } \\
\text { Difference }\end{array}$} \\
\hline & & $\mathbf{F}$ & Sig. & $\mathbf{t}$ & df & $\begin{array}{l}\text { Sig. } \\
\text { (2-tailed) }\end{array}$ & & \\
\hline ConExp & Equal variances assumed & 2.154 & .150 & 2.179 & 40 & .035 & -8.28571 & 3.80249 \\
\hline Posttest & Equal variances not assumed & & & 2.179 & 35.220 & .036 & -8.28571 & 3.80249 \\
\hline
\end{tabular}

In order to run a t-test, the researcher had to meet one assumption and that was the homogeneity of variances. As it can be seen in table 4.8 above, the two groups were homogenous in terms of their variances as a condition to apply the t-test. As displayed in Table 4.8 above, the Levene $\mathrm{F}$ of 2.154 had a probability of .150 . Since the probability associated with the Levene $\mathrm{F}$ was higher than the significance level of .05 , it could be reasoned that the two groups enjoyed homogenous variances on the post-test of the idiom test.

As already shown in table 4.8, the mean scores for the experimental and control groups were 63.04 and 54.76 respectively. As it can be seen in table 4.8 above, the probability of $\mathrm{t}(2.17)$ had the sig (.035), that is lower than the significance level of .05 . Based on the results, it could be concluded that there was a significant difference between the mean scores of the two groups on the posttest of the idiom test. The STAD group performed better on the post-test of idiom test. Thus, it could be concluded that the null-hypothesis which was "Using STAD technique does not have any effect on idiom learning of Iranian low-intermediate EFL learners" was rejected, putting emphasis on the superiority of the STAD technique in learning idiomatic expressions.

In order to find an answer to the research hypothesis, an independent t-test was run to compare the mean scores of males and females. The second null hypothesis was:

There is no significant difference between the idiom learning of male and female language learners who used the STAD technique.

Table 4.9 below shows the result of the independent t-test for the idiom scores between males and females.

Table 4.9. Independent t-test for the idiom scores between males and females

\begin{tabular}{|c|c|c|c|c|c|c|c|c|}
\hline \multicolumn{9}{|c|}{ Independent Samples Test } \\
\hline & & \multicolumn{2}{|c|}{ Levene's Test for Equality of Variances } & \multicolumn{5}{|c|}{ t-test for Equality of Means } \\
\hline & & $\mathbf{F}$ & Sig. & $\mathbf{t}$ & df & $\begin{array}{l}\text { Sig. } \\
\text { (2-tailed) }\end{array}$ & $\begin{array}{l}\text { Mean } \\
\text { Difference }\end{array}$ & $\begin{array}{l}\text { Std. Error } \\
\text { Difference } \\
\end{array}$ \\
\hline Exp & Equal variances assumed & .007 & .934 & .103 & 19 & .919 & -.68269 & 6.64322 \\
\hline Posttest & Equal variances not assumed & & & .102 & 14.631 & .920 & -.68269 & 6.68954 \\
\hline
\end{tabular}

The mean scores for the male and female participants were

62.62 and 63.30respectively. As it can be seen in table 4.9 
above, the probability of $\mathrm{t}(.103)$ had the sig (.919), that is much higher than the significance level of .05. Based on the results, it could be concluded that there was not a significant difference between the mean scores of the males and females on the posttest of the idiom test. The STAD group performed better on the post-test of idiom test; however, nothing was witnessed concerning the dominance of one sex over the other $(t(19)=.103, p>0.05)$. Thus, it could be concluded that the null-hypothesis which was "There is no significant difference between the idiom learning of male and female language learners who used the STAD technique." was accepted putting emphasis on the equality of the two genders who received STAD technique in learning idiomatic expressions.

The findings in the present study have provided evidence that is consistent with more general claims about cooperative learning and STAD technique. Momtaz and Garner (2010) asserted that using these methods (cooperative learning methods), certain process of collaborative reading were identified, including brainstorming, paraphrasing, and summarizing. Also, in their research Rahimi and Tahmasebi (2010) concluded: they (students) were no longer afraid of making mistakes; their peers had already observed their mistakes and helped them to overcome the problems. Moreover, their peers were within their reach to help them when they ran out of some words.

Jililifar (2010) found that STAD technique is an effective technique in improving EFL reading achievement of college students at the pre-intermediate level of English, which confirms the findings by Ghaith (2003) who reported similar results with regard to the positive effects of CL in improving reading comprehension achievement. However, what makes the present study significant is the superiority of STAD as one technique in cooperative learning among college level learners.

The results of this research suggest that students working cooperatively consistently outperform students attending in a lecture-based class. These findings support the evidence of Cheng (2006) that the average scores of students in cooperative learning were about two points higher than those of students in a traditional teacher- based English class. Jililifar (2010) found that STAD technique is an effective technique in improving EFL reading achievement of college students at the pre-intermediate level of English, which confirms the findings by Ghaith (2003) who reported similar results with regard to the positive effects of CL in improving reading comprehension achievement. However, what makes the present study significant is the superiority of STAD as one technique in cooperative learning among college level learners.

The results of this research suggest that students working cooperatively consistently outperform students attending in a lecture-based class. These findings support the evidence of Cheng (2006) that the average scores of students in cooperative learning were about two points higher than those of students in a traditional teacher- based English class.

\section{Conclusion}

Although students working in STAD group had a significantly higher performance in learning idioms compared to the students working in traditional methods it is not implied that participants should do everything in groups; individual work and whole class instruction have their righteous place in education. According to Johnson and Johnson (1994) there are always students who choose to work alone. These students need to be instructed on communicative skills such as how to listen, help, and give opinion. In order to have successful teams, participants need to get familiar to each other and try to create the atmosphere of confidence, fair interaction, and constructiveness amongst themselves (Johnson et al., 1995). In the light of the results and conclusions of the present study, it is suggested that future studies can change the role of the teacher from being the main source of teaching process to that of facilitating, guiding, managing and encouraging. When techniques like STAD become entrenched into the learning culture as a whole, cooperative learning will become more natural for students. It is not easy to implement STAD techniques in one small corner of the overall curriculum while the other areas of the curriculum remain highly competitive and teacher-centered. So, the educational culture as a whole should be changed so that STAD becomes the norm for all students in all subjects.

\section{References}

[1] Ambrose, J. (2000). Why idioms are important for English language learners? Retrieved March 25, 2014, from lib.chdu.edu.ua/pdf/zbirnuku/7/37.pdf.

[2] Bejarano, Y. (1987). A cooperative small-group methodology in the languageclassroom. TESOL Quarterly, 21 (3), 483-504.

[3] Cheng, K. (2006). Does cooperative learning enhance the residual effects of student interpersonal relationship skills? A case study at a Taiwan Technical College. The Journal of American Academy of Business, 10(1), 312-316.

[4] Ghaith, G. M. (2003). Effects of the learning together model of cooperative learning on EFL reading achievement, academic self-esteem, and feelings of school alienation. Bilingual Research Journal, 27(3), 65-79.

[5] Gillett, A. (2004). Speak English like an American. Learn the idioms and expressions that will help you speak like a native. NY: Language Success Press.

[6] Hamidi, H., \& Montazeri, M. (2014). Dictionary of second language acquisition. Retrieved March 10, 2015, from http://www.iranelt.com/index.php/introduction-to-sla.

[7] Harmer, J. (2001).The practice of English language teaching (3rd ed.). UK: Pearson Education Limited.

[8] Jalilifar, A. (2010). The effect of cooperative learning techniques on college students' reading comprehension. International Journal of Educational Technology and Applied $\begin{array}{lll}\text { Linguistics, } & 38(1), & 96-108 .\end{array}$ http://dx.doi.org/10.1016/j.system.2009.12.009. 
[9] Johnson, W., Johnson, R., \& Smith, K. (1995). Cooperative Learning and Individual Achievement in Secondary Schools. In J. F. Pedersen \& A. D. Digby, (Eds.), Secondary schools and cooperative learning: Theories, models and strategies ( $\mathrm{pp}$. 3-54). New York: Garland Publishing Inc.

[10] Johnson, D. W., \& Johnson, R. T. (1999). Making cooperative learning work. Theory Into Practice, 38 (2), 67-73.

[11] Johnson, D. W.\& Johnson, R.(2005) New Development in social Interdependence Theory. Genetic, Social, \&General Psychology Monographs, 131(4), 285-296.

[12] Lia, Y. (2002). A study of Taiwanese junior high school students' EFL learning motivation and learning strategies. Masters' thesis: National Changhua University of Education.

[13] McArdle, G. (2005). The free rider and cooperative learning groups: perspectives from faculty members. Lendi Nova Southeastern University. ERIC \#: (ED 492459).

[14] Momtaz, E., \& Garner, M. (2010). Does collaborative learning improve EFL learners" reading comprehension? Journal of linguistics and language teaching, 1(1), 15-36.

[15] Panitz, T. (1997).Collaborative versus cooperative learning: A comparison of the two concepts which will help us understand the underlying nature of interactive learning. Retrieved March 20, 2014, from http://home.capecod.net/ tpanitz/tedsarticles/coopdefinition.ht $\mathrm{m}$.

[16] Rahimi, A., \&Tahmasebi, S. (2010). Mediating Iranian EFL Learners: Private speech and scaffolding in reading comprehension. Linguistic \& Literary Broad Research and Innovation, 1(2), 56-71.
[17] Rivers, W. M. (1981).Teaching foreign language skills (2nd ed.). Chicago: University of Chicago Press.

[18] Slavin, R. E. (1987).Cooperative learning and the cooperative school. Educational Leadership, 45 (3), 7-13.

[19] Slavin R. E. 1(994). Outcome-based education is not mastery learning. Educational Leadership, 51 (6), 14-22.

[20] Slavin, R. E. (1995).Cooperative learning: Theory, research and practice. NJ: Prentice Hall.

[21] Slavin, R. E. (1999). Comprehensive approaches to cooperative learning. Theory into Practice, 38 (2), 74-79.

[22] Slavin, R. E. (2011).Instruction based on cooperative learning. In R. E. Mayer \& P. A. Alexander (Eds.), Handbook of research on learning and instruction (pp.344-360). New York: Taylor \& Francis.

[23] Tran, V. D., \& Lewis, R. (2012). Effects of Cooperative Learning on Students at AnGiang University in Vietnam. International Education Studies, 5(1), 86- 99. Retrieved from http://dx.doi.org/10.5539/ies.v5n1p86

[24] Yu, E. (1995). Successful cooperation in EFL teaching: A classroom study in writing. Proceedings of the 14th Conference on English Teaching and Learning in the R.O.C. 253-72. Taipei: Crane.

[25] Zakaria, E., Chin, C.L., \& Daud.Y.(2010). The effect of cooperative learning on students mathematics achievements and attitude towards mathematics. Journal of Social Sciences, 6(2), 272-275. Retrieved from http://dx.doi.org/10.3844/jssp.2010.272.275 